\title{
Growth of the Pacific oyster (Crassostrea gigas) in a high-turbidity environment: Comparison of model simulations based on scope for growth and dynamic energy budgets
}

\author{
Laurent Barille $^{a, *}$, Astrid Lerouxel ${ }^{a}$, Mickaël Dutertre ${ }^{a}$, Joël Haure ${ }^{b}$, Anne-Laure Barillé ${ }^{c}$, \\ Stéphane Pouvreau ${ }^{d}$ and Marianne Alunno-Bruscia ${ }^{d}$
}

\author{
a Université de Nantes, Equipe Mer-Molecules-Santé EA 2160, Faculté des Sciences et des Techniques, B.P. 92 \\ 208, 44322 Nantes Cedex 3, France \\ b IFREMER, Laboratoire Conchylicole des Pays de la Loire, Polder des Champs, Bouin, F-85230 France \\ ${ }^{c}$ Bio-Littoral, Faculté des Sciences et des Techniques, B.P. 92 208, 44322 Nantes Cedex 3, France \\ d IFREMER, RBE-PFOM-PI, 11 Presqu'île du Vivier, 29840 Argenton-en-Landunvez, France \\ *: Corresponding author : Laurent Barillé, tel: 33 (0)2 51125655 ; fax: 33 (0)2 51125668 \\ email address : laurent.barille@univ-nantes.fr
}

\begin{abstract}
:
We compared growth simulations by dynamic energy budget (DEB) and scope for growth (SFG) models of the Pacific oyster Crassostrea gigas, cultivated in Bourgneuf Bay on the French Atlantic coast. This bay is located at a latitude in the middle of the European range of the species, and is characterized by high concentrations of suspended particulate matter (SPM) and a marked gradient between high-turbidity sites in the north (daily SPM $>500 \mathrm{mg} \mathrm{L}^{-1}$ ) and intermediate-turbidity sites in the south. The models use two forcing variables: seawater temperature and food density. We tested two indices of food availability: chlorophyll a and microalgal concentrations. In the SFG model, food intake is simulated by a type-II Holling functional response, as in the DEB formulation, and the effect of turbidity in both models is therefore taken into account principally through the half-saturation coefficient for this functional response. Chlorophyll a concentrations were three to four times higher at the high-turbidity site, but oyster growth rates were significantly lower at this site than at the intermediate-turbidity site. A comparison of observed and simulated values showed that the DEB model performed better than the SFG model if microalgal concentration was used as an index of food availability, with the SFG model underestimating oyster growth in summer and autumn. However, the SFG model was much more efficient if chlorophyll a concentrations were used, with the DEB model systematically overestimating summer and autumn growth. This comparison suggests that both SFG and DEB simulations could be improved, to give a more accurate description of oyster growth in a turbid environment, and that the pre-ingestive selection mechanisms used by suspension feeders in turbid environments should probably be included in the formulation of feeding processes.
\end{abstract}

\section{Highlights}

The growth of Pacific oyster was studied in a high-turbidity ecosystem. At the highest turbidity site, the growth was lower compared to an intermediate turbidity site, in spite of a high availability of food resources. Growth was simulated by two models (Scope For Growth vs. Dynamic Energy Budget) showing different simulations according to the food quantifier tested (chlorophyll $a$ vs. cell concentration). Both models could be improved by including pre-ingestive feeding responses, playing a significant role for suspension-feeders inhabiting turbid environments.

Keywords : oyster; Dynamic Energy Budget model; scope for growth model; turbidity 


\section{Introduction}

Models simulating the growth of suspension-feeding bivalves are cognitive tools for improving our understanding of the functioning of shellfish ecosystems dominated by aquaculture. This knowledge is crucial if we are to develop relevant management strategies for optimizing production and limiting the impact on the environment (Raillard and Ménesguen, 1994; McKindsey et al., 2006; Cugier et al. 2010). These models may also be useful for assessing the invasion of northern European estuaries by feral oysters, which form large, dense reefs (Cognie et al., 2006; Troost, 2010).

Energy budget models for bivalves are based on the modeling of ecophysiological processes and energetics in response to environmental variation. There are various types of energetic models, generally classified as "net production" or "scope for growth" models and "assimilation" or dynamic energy budget (DEB) models (e.g. van der Meer 2006). In the last decade, DEB models (Kooijman, 2010) have increasingly been developed, for various species (van der Veer and Alunno-Bruscia, 2006; van der Veer et al., 2006), according to the theory developed by Kooijman (2010). The DEB theory has been successfully applied to the modeling of growth and reproduction in the Pacific oyster Crassostrea gigas (Pouvreau et al., 2006; Ren and Schiel, 2008; Bourlès et al., 2009; Alunno-Bruscia et al., submitted, this issue), one of the principal shellfish cultivated worldwide (FAO, 2004).

In previous versions of the Pacific oyster-DEB model, feeding processes were described purely in terms of ingestion and assimilation (Pouvreau et al., 2006; Ren and Schiel, 2008; Bourlès et al., 2009). These models did not consider pre-ingestive feeding processes, such as particle selection, which is a characteristic physiological response of suspension-feeding bivalves, associated with pseudofeces production (Ward et al., 1997; Beninger et al., 2008). Pseudofeces production, which is essentially associated with the retention of inorganic particles on the gills, has been modeled according to DEB theory (Kooijman, 2006), but the resulting complex formulation has yet to be incorporated into more recent versions of the oyster-DEB model (Bourlès et al., 2009). In their present formulation, oyster-DEB models do not consider particulate inorganic matter (PIM) as a forcing variable, even in estuarine environments (Grangeré et al., 2009). PIM is not explicitly used in the DEB model, but its effect is integrated into the half-saturation coefficient, $X_{k}$, which describes food ingestion through the functional response $f$ (Kooijman, 2010). Pouvreau et al. (2006) suggested that this coefficient was site-specific, varying with seston load and food quality and/or quantity (see also Alunno-Bruscia et al., submitted, this issue).

A net production model based on the scope for growth (SFG) concept (Bayne 1976) has been developed for C. gigas by Barillé et al. (1997a). This SFG model was developed from empirical relationships describing feeding processes and resource allocation, through the use of allometric relationships. In this study, we modified the SFG model for C. gigas significantly, in several ways. The formulation of feeding was simplified to take into account criticisms concerning overparametrization (van der Veer and Alunno-Bruscia, 2006) and a new formulation made use of the functional response $f$ from the DEB model, to describe the relationship between environment and ingestion rate. With this formulation, we tested the same forcing variables in the two models. The effects of turbidity were considered only implicitly, through the $X_{k}$ parameter and absorption efficiency. Classical SFG energy allocation, which assumes that the net production (assimilation-respiration) is immediately available for growth and reproduction, was also modified, as described by Brylinsky and Sephton (1991), with the addition of a reserve-gonad compartment acting as a buffer. Finally, reproductive physiology was reformalized on the basis of fine-scale temporal data for oysters in Bourgneuf Bay (Dutertre et al. 2009, 2010).

In this study, we compared simulations of growth obtained with the DEB and SFG models for 18-month diploid Pacific oysters reared at two sites in Bourgneuf Bay, an important oyster- 
farming area on the western Atlantic coast of France, corresponding to the middle of the range of latitudes over which $C$. gigas is found in Europe. This bay is a highly turbid macrotidal ecosystem in which the concentrations of suspended particulate matter frequently exceed the physiological thresholds triggering a change in feeding responses in $C$. gigas (Barillé et al., 1997b). Moreover, this oyster-farming site is characterized by low growth rates (Barillé-Boyer et al., 1997) and is confronted by a problem of decreasing yields due to the proliferation of feral oysters (Dutertre et al., 2010). The new version of SFG model tested here, modified from that of Barille et al. (1997a), is presented in more detail than the DEB model, which was fully described by Bourlès et al. (2009). We tested two indices of food availability in this study: chlorophyll a concentration (in $\mu \mathrm{g} \mathrm{L}^{-1}$ ) and microalgal concentration (in number of cells $\mathrm{L}^{-1}$ ).

\section{Materials and methods}

\subsection{Study area and experimental data}

Two experimental oyster-farming sites were selected in Bourgneuf Bay (Fig. 1), which is located on the French Atlantic coast and is characterized by a marked gradient of SPM concentration (Dutertre et al. 2009). The northern high-turbidity (HT) site, La Coupelasse (47 $1^{\prime} 34.7^{\prime \prime} \mathrm{N}, 2^{\circ} 1^{\prime} 55.9^{\prime \prime} \mathrm{W}$ ), is an intertidal mudflat in which more than $44 \%$ of the total weight of sediment is accounted for by particles with a diameter of less than $44 \mu \mathrm{m}$, and which supports a high microphytobenthic biomass (Méléder et al., 2003). The southern intermediate-turbidity (IT) site, Graisselous ( $\left.46^{\circ} 57^{\prime} 2.6^{\prime \prime} \mathrm{N}, 2^{\circ} 7^{\prime} 53.4^{\prime \prime} \mathrm{W}\right)$, is characterized by a sand-mud bottom in which less than $10 \%$ of the total weight of sediment corresponds to particles with a diameter of less than $44 \mu \mathrm{m}$. In February 2005, 18-month-old hatchery-born oysters were placed in plastic mesh bags (250 individuals per bag), which were then tied to oyster racks $60 \mathrm{~cm}$ above the bottom, at both experimental sites. Over a period of one year (Feb. 2005-Feb. 2006), we collected 30 randomly selected oysters per month, or per fortnight from May to September, at the HT and IT sites, for the identification and quantification of spawning events. The same sampling plan was followed during the next year, with a new batch of 18-month-old hatchery-born oysters installed in February 2006 at the IT and HT sites. Soft tissues were freeze-dried for $48 \mathrm{~h}$ and weighed to obtain the dry tissue mass (g). Dry tissues were then processed for biochemical determinations (lipids, carbohydrates, proteins; see Méléder et al. (2001) for the methods used). In 2005 and 2006, seawater temperature, SPM and chlorophyll a concentrations were recorded at 15-minute intervals, with multi-parameter water quality probes (YSI 6600) fixed below the oyster racks, at both the HT and IT sites (see Dutertre et al., 2009 for details). In model simulations, chlorophyll a concentration was compared with microalgal concentration, with a view to identifying the most reliable index of the quantity of food available. The total number of microalgal cells was determined by microscopic examination of seawater samples collected twice monthly at a western low-turbidity (LT) site of Bourgneuf Bay, Bois de la Chaise (Fig. 1), through a phytoplankton monitoring network (REPHY IFREMER, Quadrige database, 2005; 2006). 


\subsection{SFG and DEB models}

\subsubsection{SFG model}

The SFG model used in this study was derived from that developed by Barillé et al. (1997a) to simulate Pacific oyster growth in Marennes-Oléron Bay (France), a turbid shellfish ecosystem. We modified the structure of this model in terms of feeding processes and energy allocation (Fig. 2). Comparison of this SFG model with the DEB growth model for $C$. gigas (Bourlès et al. 2009) was facilitated by changing the forcing variables of the SFG model: food density, estimated by chlorophyll a concentration or microalgal concentration, and seawater temperature. As for the DEB model (Kooijman, 2010), food uptake was modeled by a type-II Holling functional response, f. Feeding processes were therefore represented solely in terms of the ingestion and absorption of particulate organic matter (POM). The SFG model simulates the variation of three state variables: shell mass (SHELL), somatic mass (SOMA) and reserve-gonad mass (RESGON). These state variables and the other main variables of the model, as well as the model parameters, are presented in Table 1. The initial values of the state variables were estimated by biometric and biochemical measurements as detailed in the previous paragraph. RESGON was estimated by adding together the amounts of lipids and carbohydrates, whereas SOMA, which we assumed to consist essentially of proteins, was calculated as the difference between the measure of dry tissue mass and the sum of lipid and carbohydrate masses (Méléder et al., 2001). The simulated dry tissue mass (DTM) was calculated as the sum of SOMA plus RESGON.

\section{Feeding processes}

Organic ingestion (ING ${ }_{\text {org }}$ ) was formulated with a maximal organic ingestion rate $\left(I n g_{\max }\right)$, a functional response (f) and somatic mass (SOMA). The relationship between ingestion and somatic mass is defined by an allometric coefficient (Mølhenberg and Riisgård, 1979). The

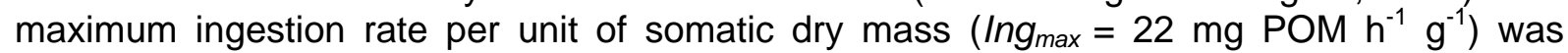
obtained from Barillé et al. (2003). The scaled functional response, f (dimensionless), depends on food density $X$ and the half saturation coefficient $X_{k}$ :

$\mathrm{ING}_{\text {org }}=\left(\mathrm{Ing}_{\max }-\mathrm{ING}_{\text {temp }}\right) \cdot \mathrm{f} \cdot(\mathrm{SOMA})^{\mathrm{b}} \quad\left(\mathrm{mg} P O M \mathrm{~h}^{-1}\right)$ with $\mathrm{f}=\mathrm{X} /\left(\mathrm{X}+\mathrm{X}_{\mathrm{k}}\right)$

The effect of temperature on the enzyme kinetics associated with feeding was integrated into the calculation of ingestion rates through the function ING $\mathrm{Itemp}_{\text {: }}$

$$
\mathrm{ING}_{\text {temp }}=\text { ing }_{1} \cdot\left(\mathrm{TEMP}-\mathrm{ing}_{2}\right)^{2} \quad\left(\mathrm{mg} \mathrm{h}^{-1} \mathrm{~g}^{-1}\right)
$$

This formulation is based on the $C$. gigas clearance rate model (Bougrier et al., 1995), with $19^{\circ} \mathrm{C}$ as the optimum temperature $\left.\left(i_{2}\right)_{2}\right)$; $i n g_{1}$ was specifically reformulated for this study. Seawater temperature is represented by the variable TEMP. The excretion of dissolved matter is ignored in this model, and absorbed organic matter is considered to be assimilated organic matter. Previous studies have demonstrated that absorption efficiency decreases with the dilution of organic matter by inorganic particles in bivalve digestive systems (Hawkins et al., 1986; Bayne et al., 1987). In their study, Barillé et al. (1997b) used the organic fraction of $C$. gigas stomach contents to describe absorption efficiency. Here, we used a low value of absorption efficiency $(a e=0.25)$, to account for this negative effect of inorganic matter. Finally, organic matter absorption was formulated as follows:

$$
\mathrm{ABS}_{\text {org }}=\mathrm{ae} \cdot \mathrm{ING}_{\text {org }} /(1000.24) \quad\left(\mathrm{g} \mathrm{POM} \mathrm{d}^{-1}\right) \text {. }
$$




\section{Metabolic costs}

The metabolic costs associated with feeding, growth, reproduction and basal maintenance are estimated by the oxygen consumption model established by Bougrier et al. (1995), which is dependent on temperature and is linked to SOMA by an allometric coefficient (br), based on the assumption that reserves and gonads do not require energy for maintenance (Van Haren and Kooijman, 1993). However, studies on metabolic costs in C. gigas (Ropert and Goulletquer, 2000; Haure et al., 2003) have suggested that the formulation of Bougrier et al. (1995) significantly underestimates metabolic costs at high temperatures. We therefore corrected the original formulation with a two-parameter exponential function (Haure et al., 2008). The $\mathrm{mgO}_{2} \mathrm{pom}$ parameter converts oxygen concentration into a mass of POM (Barillé et al., 1997a).

$\mathrm{RESP}=r e s p_{1} \cdot \exp ^{(\text {resp2 } \cdot \text { TEMP) }} \cdot \mathrm{SOMA}^{b r} \cdot \mathrm{mgO}_{2} \mathrm{pom} /(1000 \cdot 24) \quad\left(\mathrm{g} \mathrm{POM} \mathrm{d}^{-1}\right)$

\section{Energy allocation}

In SFG models, energy balance is the difference between the energy gained through feeding processes and metabolic costs. In the initial version of the model, the net production (ABSorg-RESP) was allocated to different compartments (Barillé et al., 1997a). A fraction of energy was allocated first to the shell, then to the somatic compartment, until a maximum somatic growth was achieved. Finally, any excess energy was allocated to the reserve-gonad compartment. In the new formulation, we retained the allocation rules but took metabolic costs into account a posteriori, in either the somatic or the reserve-gonad compartment (Brylinsky and Sephton, 1991; Barillé, 1996), as a function of gametogenesis, the key process in reproduction (Fig. 2). Outside periods of gametogenesis, metabolic costs are deducted from the reserve-gonad compartment and shell growth is kept maximal. In this case, daily energy budgets for the shell (SHELL GAIN), soma (SOMA GAIN) and reservesgonad (RESGON GAIN) compartments are calculated as follows:

$$
\begin{array}{lr}
\text { SHELL GAIN }=\text { shellcoef. ABS } \text { org } & \left(\mathrm{g} \mathrm{d}^{-1}\right) \\
\text { SOMA GAIN }=\text { min }\left(\text { max }_{\text {SOMA }} ;(\text { ABS } \text { org }- \text { SHELL GAIN })\right) & \left(\mathrm{g} \mathrm{d}^{-1}\right) \\
\text { RESGON GAIN = ABS }{ }_{\text {org }}-\text { SHELL GAIN - SOMA GAIN - RESP } & \left(\mathrm{g} \mathrm{d}^{-1}\right)
\end{array}
$$

The daily fraction of energy gain allocated to shell growth, represented by the parameter shellcoef $=5 \%$, as proposed by Méléder et al. (2001). If the energy acquired through feeding processes is not sufficient to cover metabolic costs $\left(\right.$ ABS $\left._{\text {org }}<\mathrm{RESP}\right)$, shell growth stops (SHELL GAIN $=0)$. Maximal somatic growth $\left(\max _{\text {SOMA }}\right)$ was estimated from biometric and biochemical data for juvenile and adult oysters in Bourgneuf Bay in 2005 and 2006. Somatic variations were estimated from the difference between oyster dry tissue mass and the sum of lipid and carbohydrate masses. Below a somatic mass threshold of $1.5 \mathrm{~g}(\mathrm{sm}), \max _{\text {SOMA }}$ was a linear function of somatic mass; above sm, max ${ }_{\text {SOMA }}$ was constant. During periods of gametogenesis, metabolic costs are deducted from the soma and shell growth is reduced by 50 \% (shellgam; Méléder et al., 2001). In this case, energy allocation is modeled as follows:

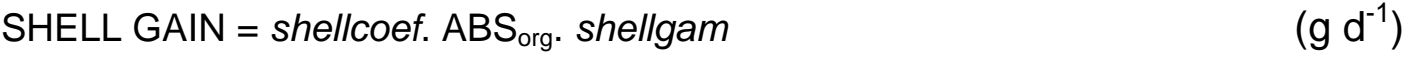

$$
\begin{aligned}
& \text { SOMA GAIN = min }\left(\max _{\text {SOMA }} ;\left(\text { ABS }_{\text {org }}-\text { SHELL GAIN }\right)\right)-\text { RESP } \quad\left(g^{-1}\right) \\
& \text { RESGON GAIN = ABS } \text { org }_{-} \text {SHELL GAIN - SOMA GAIN } \quad\left(\mathrm{g} \mathrm{d}^{-1}\right)
\end{aligned}
$$


Biochemical analyses indicated that the reserve-gonad compartment was never totally empty, with this compartment always accounting for at least $20 \%$ of the mass of the soma (Haure et al. 2008). This value was used as a threshold (rgs1) when subtracting metabolic costs from the somatic compartment, whatever the status of the reproductive cycle.

\section{Reproduction}

The reproductive cycle of $C$. gigas closely follows seasonal variations in seawater temperature. In Bourgneuf Bay, Dutertre et al. (2009) showed that the onset of gamete maturation was associated with a threshold temperature of about $8^{\circ} \mathrm{C}$. Histological analyses on farmed oysters also suggested that the ratio between reserves-gonads and soma did not exceed a mean value of 0.6 (Dutertre et al., 2009). Gametogenesis periods were formulated in relation to these thresholds: $t g$ is the minimal temperature for the triggering of gamete maturation whereas the second threshold $\left(\mathrm{rgs}_{2}\right)$ corresponds to the maximum filling of the gonad by gametes (Dutertre et al., 2009). Gametogenesis thus occurs if TEMP $>\operatorname{tg}$ and (RESGON/SOMA) $<$ rgs $_{2}$.

In the model, spawning depends on two conditions: a temperature threshold, $t s=18^{\circ} \mathrm{C}$ and a RESGON threshold, $r g s p=35 \%$, based on a gonosomatic index (Pouvreau et al., 2006; Dutertre et al., 2009). The mass of the reserve-gonad compartment lost by spawning (SP) was estimated from histological analyses (Dutertre et al., 2009) and found to be equivalent to a spawning intensity of $60 \%$ (cs):

If TEMP $>$ ts and (RESGON/SOMA) $>$ rgsp then SP $=c s$. RESGON

Tissue recovery requires gametogenesis and energy allocation to the shell to stop after spawning (Méléder et al. 2001). These post-spawning periods are included in the model through two time-lag parameters: $t / g=7$ days and t/shell $=15$ days (Méléder et al. 2001).

\subsubsection{The DEB model}

A detailed description of the validated Dynamic Energy Budget (DEB) model for $C$. gigas has been provided by Bourlès et al. (2009), based on the DEB theory developed extensively by Kooijman (2010). The general framework of the oyster-DEB model used, including the equations and DEB parameter values (Table 2), were kept similar to those in the study by Bourlès et al. (2009). We therefore provide only a brief outline of this model here.

The dynamics of growth and reproduction can be fully described by three differential equations describing the dynamics of the energy reserve, $E$, the dynamics of the energy allocated to structural body volume, $E_{V}$, and the storage and use of energy allocated to development (complexity acquisition before sexual maturity) and reproduction, $E_{R}$ (Fig. 2). Only the half-saturation coefficient $X_{K}$ is calibrated. Food uptake is assumed to follow a typeII Holling function response dependent on food density $X$ (expressed in $\mu g_{c h l-a} L^{-1}$ or number of cells $L^{-1}$ in this study) and to be proportional to the surface area of the structural body volume $\left(V, \mathrm{~cm}^{3}\right)$. The rate of ingestion $\dot{J}_{X}\left(\mathrm{~J} \mathrm{~d}^{-1}\right)$ can therefore be written as

$$
\dot{J}_{X}=\left\{\dot{J}_{X m}\right\} \cdot f \cdot V^{2 / 3} \text { with } f=\left(\frac{X}{X+X_{k}}\right)
$$

where $f$ is the scaled functional response (dimensionless), $X_{K}$ is the saturation coefficient or Michaelis-Menten constant and $\left\{\dot{J}_{X m}\right\}$ the area-specific maximum ingestion rate, expressed 
in $\mathrm{J} \mathrm{d}^{-1} \mathrm{~cm}^{-2}$. As a first approximation, the efficiency of absorption ( $\kappa_{\mathrm{A}}$, dimensionless) is assumed to be constant, so the rate of energy assimilation $\dot{p}_{A}$ becomes

$\dot{p}_{A}=\kappa_{A} \dot{J}_{X}$

Due to the energy conservation law, the dynamics of the reserve $E$ can be written as

$\frac{d E}{d t}=\dot{p}_{A}-\dot{p}_{C}$

where $\dot{p}_{c}$ denotes the energy consumed (fixed and dissipated) by the body tissues and is known as the catabolic power or utilization rate.

In DEB theory, a fixed fraction $\mathrm{k}$ of the utilization rate, $\dot{p}_{C}$, is allocated to structural growth, which also accounts for maintenance $\dot{p}{ }_{M}\left(\mathrm{~J} \mathrm{~cm}^{-3} \mathrm{~d}^{-1}\right)$. Development or reproduction results from a balance between rest $(1-\kappa) \dot{p}_{C}$ and maturity maintenance, $\dot{p}_{J}$. The dynamics of the energy allocated to structural body volume $E_{V}$ and to development or reproduction $E_{R}$ can therefore be expressed as

$\frac{d E_{V}}{d t}=\kappa \dot{p}_{C}-\dot{p}_{M}$

$\frac{d E_{R}}{d t}=(1-\kappa) \dot{p}_{C}-\dot{p}_{J}$

The induction of spawning is dependent on gonado-somatic index (GI, \%), defined as the ratio of gonad mass to total flesh mass, and a minimal temperature threshold, $T_{S}$. When these two thresholds are reached, the reproductive buffer $E_{R}$ is totally emptied.

Physiological rates (i.e. assimilation, maintenance, structural growth) depend on body temperature through an Arrhenius relationship within the species-specific tolerance range for temperature (e.g. van der Meer 2006, Kooijman 2010). Outside the boundaries of speciesspecific temperature tolerance, the extensive Arrhenius relationship becomes:

$$
\dot{k}(T)=\dot{k_{1}} \cdot \exp \left\{\frac{T_{A}}{T_{1}}-\frac{T_{A}}{T}\right\} \cdot\left(1+\exp \left\{\frac{T_{A L}}{T}-\frac{T_{A L}}{T_{L}}\right\}+\exp \left\{\frac{T_{A H}}{T_{H}}-\frac{T_{A H}}{T}\right\}\right)
$$

where $\dot{k}(T)$ is the value of the physiological rate at ambient temperature $\mathrm{T}$ (in $\mathrm{K}$ ), $\dot{k}$ is the value of the physiological rate at a chosen reference temperature $T_{1}, T_{L}$ and $T_{H}$ are the lower and upper boundaries of the tolerance range, respectively, $T_{A}$ is the so-called Arrhenius temperature (in $\mathrm{K}$ ) and $\mathrm{T}_{A L}$ and $\mathrm{T}_{A H}$ are the Arrhenius temperatures (in $\mathrm{K}$ ) for the rate of decrease at the two boundaries.

The state variables, expressed in energy, are converted into mass according to specific relationships (see Pouvreau et al. 2006). The structural volume density, $\rho$, is $1 \mathrm{~g} \mathrm{~cm}^{-3}$. Storage energy (mostly in the form of glycogen) is converted according to the ratio $\mu_{E}=$ $17550 \mathrm{~J} \mathrm{~g}^{-1}$. Total dry tissue mass (DTM, $\mathrm{g}$ ) is therefore equal to

$D F M=\frac{E+E_{R}}{\mu_{E}}+\frac{E_{V}}{\left[E_{G}\right]} \rho$

where $\left[E_{G}\right]$ denotes the volume-specific cost for growth $\left(\mathrm{J} \mathrm{cm}^{-3}\right)$, a constant for structural mass including all types of overheads, and not only the costs of biosynthesis. 
Total length $L$ is calculated with the shape coefficient $\delta_{V}$ and structural body volume $\left(V, \mathrm{~cm}^{3}\right)$, as follows:

$L=\frac{V^{1 / 3}}{\delta V}$ with $V=\frac{E_{V}}{\left[E_{G}\right]}$

The SFG and DEB models differ markedly in their approaches (van der Meer, 2006, 2009; Lika and Kooijman, this issue); the body size scaling relationships are a good example of these differences. However, the model versions compared in this study share some common features. The main differences and similarities between the two models regarding key physiological processes are therefore synthesized in Table 3 (see also Fig. 2).

\subsection{Model simulations}

The SFG and DEB models were implemented in STELLA 9.0.3 software, with daily time steps. Simulations were conducted with food densities expressed in chlorophyll a concentration $\left(\mu \mathrm{g} \mathrm{L}^{-1}\right)$ or phytoplankton concentration (cells $\mathrm{L}^{-1}$ ). The half saturation coefficient $X k$, used in both the SFG and DEB models, was fitted freely for each index of food availability. For each simulation, growth, expressed in dry tissue mass (DTM) was compared with the observed data. The coefficient of determination $\left(r^{2}\right)$ was calculated to assess the quality of the simulation for each model. Sigmastat 3.1 (Systat software) was used to check the normality and heteroscedasticity of data distributions, and for subsequent statistical analyses. Growth data were analyzed by two-way ANOVA according to two factors, temporal variations of environmental factors and sites,. Student-Newman-Keuls (SNK) tests were used, when appropriate, in a posteriori analyses. Relationships between environmental factors at each site were determined by carrying out Spearman's rank correlation tests (Conover 1999).

\section{Results}

\subsection{Forcing variables}

Variations in seawater temperature followed a seasonal pattern typical of a northern temperate ecosystem, with no significant variation between sites and years (Fig. 3a, two-way ANOVA, $p=0.95$ and $p=0.77$, respectively). However, seawater temperature frequently varied more markedly at the HT than at the IT site. SPM concentrations were significantly higher at the HT site than at the IT site (Fig. 3b, two-way ANOVA, $p<0.01$ ), with an annual mean value almost five times higher in 2005 (128.38 \pm 98.24 (SD) mg. ${ }^{-1}$ vs $26.99 \pm 26.54$ (SD) mg. $\left.\mathrm{L}^{-1}, \mathrm{n}=311\right)$ and three times higher in $2006\left(103.79 \pm 82.20 \mathrm{mg} \cdot \mathrm{L}^{-1} \mathrm{vs} 31.48 \pm 23.67\right.$ $\mathrm{mg} \cdot \mathrm{L}^{-1}, \mathrm{n}=365$ ). Chlorophyll a concentrations were also significantly higher at the HT than at the IT site (Fig. 3c, two-way ANOVA, $p<0.01$ ) in 2005 (annual mean $=8.09 \pm 4.09$ (SD) $\mu \mathrm{g}$ $\mathrm{L}^{-1}$ vs $2.24 \pm 2.13$ (SD) $\mu \mathrm{g} \mathrm{L}^{-1}, \mathrm{n}=311$ ) and 2006 (annual mean $=9.15 \pm 5.70 \mu \mathrm{g} \mathrm{L}^{-1}$ vs $3.27 \pm$ $2.33 \mu \mathrm{g} \mathrm{L}^{-1}, \mathrm{n}=365$ ). Chlorophyll-a exhibited two main periods of increasing concentrations at the IT site, in spring and autumn. Variations in SPM and chlorophyll-a concentrations were positively correlated at both HT (Spearman test, $r=0.83, p<0.01$ ) and IT (Spearman test, $r=$ $0.39, p<0.01)$ sites. In 2005, microalgal concentration showed two marked increases of cell concentration in March and June (Fig. 3d). In 2006, the period of rise was shorter (two months vs four months in 2005) with two major peaks of cell concentration in April and May. A significant correlation was observed between the microalgal and chlorophyll a 
concentrations at the IT site (Spearman test, $r=0.26, p<0.01$ ); at the HT site, the $r$ value for this correlation was low $(r=0.11)$ and less significantly significant $(p<0.05)$.

\subsection{Growth of C. gigas in Bourgneuf Bay}

Field oyster DTM differed significantly between sites and years (Fig. 4, two-way ANOVA, $p<0.01$ and $p<0.05$, respectively). From February to June 2005, field oyster DTM increased at both experimental sites but was significantly higher at the IT site than at the HT site (SNKtests, $\mathrm{p}<0.05)$. A growth pattern common to both sites was observed from March to June 2006. Field oyster DTM at the IT site decreased significantly by $38 \%$ in June $2005,12 \%$ in June 2006 and 28\% in July 2006 (Fig. $4 a$ and b, SNK-tests, p<0.01). At the HT site, such decreases were observed only in June (-15\%) and July (-46\%) 2006 (Fig. d, SNK-tests, $\mathrm{p}<0.01)$ ). These decreases in DTM may be related to spawning events (Dutertre et al., 2009). In 2005 and 2006, field oyster DTM decreased slowly from the end of the summer to the following February.

\subsection{Growth simulations}

All the simulations obtained with the DEB model, using chlorophyll $a$ as an index of food availability, followed a similar pattern (Fig. 4). The DEB model tended to underestimate oyster DTM during the spring growth period, and overestimated it in the summer and autumn, after spawning events. The values of the coefficient of determination $\mathrm{r}^{2}$ obtained from linear regressions between field DTM and the values obtained in simulations were low, at 0.08 $(n=17, p=0.29$, Table 4) to $0.31(n=15, p<0.05)$. For DEB simulations based on the use of chlorophyll a concentrations as an index of food availability, values of the half-saturation coefficient $X_{k}$ differed between years and between sites. $X_{k}$ was $2.5 \mu \mathrm{g} \mathrm{L}{ }^{-1}$ and $3 \mu \mathrm{g} \mathrm{L}^{-1}$ for the

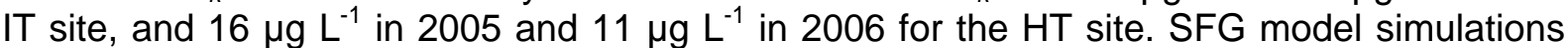
with chlorophyll a as an index of food availability gave a different pattern (Fig. 4). In 2005, the simulated DTM values underestimated growth after spawning at the IT site (Fig. 4a). In 2006, simulated DTM values closely matched observations (Fig. 4b; Table 4). At the HT site, the SFG model correctly simulated spring growth, but overestimated post-spawning DTM values, although this overestimation was less pronounced than that with the DEB model (Fig. 4c and d). Variations in the values of $X_{k}$ were different but consistent with the trend obtained with the DEB model, with higher values at the high-turbidity site: $8 \mu \mathrm{g} \mathrm{L}^{-1}$ in 2005 and $9.5 \mu \mathrm{g} \mathrm{L}^{-1}$ in

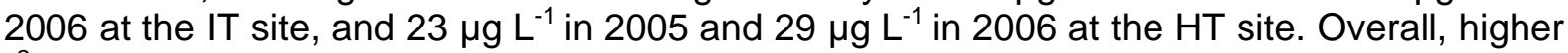
$r^{2}$ values were obtained with the SFG model (Table 4).

With the use of phytoplankton concentration as a proxy for food availability, the simulations of the DEB model matched the field data more closely than those of the SFG model (Fig 5; Table 4). The best correlations between simulated and observed DTM were obtained for the HT site in 2005 and 2006 (Figs. 5c and 5d; Table 4), with $r^{2}=0.94(n=15, p<0.001)$ and $r^{2}=0.88(n=17, p<0.001)$, respectively. However, at the IT site, the spring growth of $C$. gigas was underestimated in both years (Figs. $5 \mathrm{a}$ and $5 \mathrm{~b}$ ) and post-spawning DTM was greatly overestimated in 2006 (Fig. 5b). For these simulations, the $X_{k}$ values obtained with microalgal concentration as an index of food availability were $300 \cdot 10^{3}$ cells $\mathrm{L}^{-1}$ in 2005 and $90 \cdot 10^{3}$ cells $\mathrm{L}^{-1}$ in 2006 for the IT site, and $550 \cdot 10^{3}$ cells $\mathrm{L}^{-1}$ in 2005 and $230 \cdot 10^{3}$ cells $\mathrm{L}^{-1}$ in 2006 for the HT site. All SFG model simulations with microalgal cell concentration used as the index of food availability gave a similar pattern (Fig. 5). Spring growth was correctly simulated, whereas post-spawning DTM values were systematically underestimated. In 2005, $X_{k}$ values were $1000 \cdot 10^{3}$ cells $L^{-1}$ at both sites, whereas, in 2006 , the values obtained were $650 \cdot 10^{3}$ cells $L^{-1}$ for the IT site and $950 \cdot 10^{3}$ cells $L^{-1}$ for the HT site. 


\section{Discussion}

The northern and southern oyster-farming areas of Bourgneuf Bay are only $15 \mathrm{~km}$ apart, but they differ markedly in terms of the quantity and quality of SPM. These differences relate to differences in the type of sediment, because the fine mud particles of the HT site are more readily resuspended by the action of the tide or the wind than the coarser particles present at the IT site (Hinch et al., 1986). The hydrological features of the HT site are strongly influenced by semi-diurnal tidal cycles, with a much greater range of SPM and chlorophyll a concentrations than the IT site. Daily variations are equivalent to the annual range and are superimposed on seasonal events, such as phytoplankton blooms. Indeed, at this site, the daily resuspension of an abundant microphytobenthos biomass and of sediment makes a significant contribution to variations in chlorophyll a concentration in the water column. This accounts for the strong correlation with the seston load, as observed in turbid macrotidal systems (Barillé et al., 1997b).

In recent dynamic energy budget modeling studies on C. gigas, phytoplankton concentration has been shown to be a better quantifier of food levels than chlorophyll a concentration for the simulation of oyster growth (Bourlès et al., 2009; Grangeré et al., 2009). Unfortunately, phytoplankton concentration measurements were not available for the oyster-growing IT and HT sites studied in this experiment. We therefore recovered data for a third site (LT) at the entrance of the bay that is under neritic influence and shows marked temporal patterns. The IT site displayed seasonal variations of chlorophyll a concentration similar to the variations in microalgal concentration at the LT site. Moreover, the correlation between chlorophyll $a$ and phytoplankton concentrations was strongest at the IT site. This suggests that cells counts at the entrance of the bay were probably more representative of food availability at the IT site than at the HT site. However, recent data from 2010 showed that the phytoplankton composition below the surface at high tide did not differ significantly between the LT and HT sites (Pouvreau, unpublished data). This may account for the satisfactory simulations of the DEB model at the HT site and would suggest that microphytobenthos has a minor contribution to oyster growth. Nevertheless, discrete samples collected during tidal cycles at the level of oyster racks revealed that benthic diatom species accounted for one third of the cells (Barillé, unpublished data). The role of resuspended microphytobenthos should be further studied in this high turbidity site. As in previous studies, the DEB model simulated oyster dry tissue mass in Bourgneuf Bay more accurately when phytoplankton concentration was used as the index of food availability than when chlorophyll a was used. The SFG model was less efficient with phytoplankton concentrations used as an index of food availability, with the poorest simulations obtained in 2005 , at both sites. The underestimation of oyster growth from July onwards corresponded to a lack of food, as indicated by the cells counts. The relevance of this forcing variable remains a matter of debate, particularly for the HT site, but this suggests that the reserve-gonad compartment of the SFG may not buffer natural food variability sufficiently, compared to the role played by the reserve compartment for the DEB. By contrast, the SFG model was more efficient when chlorophyll a was used as the food proxy, with DEB systematically overestimating the summer and autumn growth of $C$. gigas. This overestimation may be due to a low food quality in autumn when the pool of suspended organic matter is characterized by a higher detritic fraction. The transformation of chlorophyll a concentration into carbon concentration using a $\mathrm{Chl} \mathrm{a:C}$ ratio with seasonal variations could probably improve the simulations of oyster growth during this period (Grangeré et al., 2009). The formulation of the effect of temperature for each model may also explain these discrepancies (Table 3 ). In the temperature range observed in our study (3$24^{\circ} \mathrm{C}$ ), the feeding processes in the DEB model are related to temperature by an exponential relationship, while the SFG model has an optimum value of $19^{\circ} \mathrm{C}$. During summer, more 
energy is therefore available for growth after spawning with the DEB formulation, through food acquisition.

The half-saturation coefficient $X_{k}$ accounted for the effect of inedible particles (silt) on ingestion by $C$. gigas in Bourgneuf Bay. For both food proxies and modeling approaches, $X_{k}$ values were lower under conditions of moderate turbidity (i.e. for the IT site, see the Results section) than in a highly turbid environment, indicating a higher food quality and/or a lesser effect of inedible particles on the filtration and ingestion processes of $C$. gigas at the IT site than at the HT site. This result confirms previous observations and conclusions for $X_{k}$, which is considered to be an environment-specific parameter in DEB approaches incorporating variability (and uncertainties) in food quality and/or availability for various bivalve species (e.g. Pouvreau et al. 2006; Bernard et al. submitted, this issue; Alunno-Bruscia et al. submitted, this issue; Filgueira et al., this issue; Wijsman et al., this issue). An alternative approach to accounting for the effect of inedible particles on the filtration process of $C$. gigas would involve explicitly including the role of silt (or inedible particles), as proposed by Kooijman (2006), through the introduction of a module for pseudofeces production (see Ren (2009) for application to Perna canaliculus). Food sources and selection efficiency are often evoked to account for discrepancies between observed and simulated dry tissue mass in filter-feeders, but the whole reproductive cycle (i.e. storage, gametogenesis, time of spawning and reproductive output) may also play a role. This cycle involves complex processes requiring careful formalization for implementation in a model. We simplified the reproduction process, by using the same reproductive processes as Bourlès et al. (2009) for the DEB model and as Barillé et al. (1997a) for the SFG model. A more detailed description of the reproductive effort in $C$. gigas, obtained with a DEB model, has recently been reported by Bernard et al. (submitted, this issue). This study led to the proposal of a new set of DEB parameters and a formalism different from that of Bourlès et al. (2009), with the addition of a state variable describing gamete production in the spring. A comparison between the simulations obtained with the two versions of the model (i.e. those of Bourlès et al. (2009) and Bernard et al., submitted, this issue) indicated that the model of Bernard et al. (submitted) gave a better description and quantification of reproductive effort for the years and sites tested.

This comparison of the simulations generated by two models suggests that both models could be improved, to give a better description of oyster growth and reproduction in a turbid environment. A revised version of the DEB-model of Bourlès et al. (2009) has recently been proposed, to improve simulation of the reproductive effort of $C$. gigas at various Atlantic sites. Based on a new set of DEB parameters and a new state variable for gonad construction (Bernard et al., this issue), this revised version, together with the classical version developed by Bourlès et al. (2009), was applied to the data for Bourgneuf Bay obtained in 2008 and 2009. Neither of the models provided a satisfactory simulation of oyster growth in either of the two years (Bernard et al., this issue). The lack of fit between observed and simulated data, whatever the version of the model used, was most pronounced after the spawning event (see Figs. 6 and 7 in Bernard et al., this issue). Bernard et al. (this issue) referred to discrepancies in water composition between the sites at which the oysters were reared and the site for which phytoplankton data were available. The SFG model was deliberately made much simpler than the initial version (Barille et al., 1997a), with the number of variables reduced from 36 to 25 , and the number of parameters from 34 to 22 . However, this simplification affected most of the formulations involving negative effects of PIM on feeding processes, and a compromise must certainly be found between overparametrization and realism (Beck, 1987). Variations in SPM concentrations greatly influence the quality of the food available to filter-feeding bivalves (Widdows et al., 1979; Bayne et al., 1989). Seston load at the HT site frequently exceeded the physiological thresholds for the cessation of filtration (192 mg. $\left.\mathrm{L}^{-1}\right)$ and pre-ingestive selection $\left(150 \mathrm{mg} \cdot \mathrm{L}^{-1}\right)$, determined for $C$. gigas (Barillé et al., 1997b). Pre-ingestive feeding mechanisms are fundamental for $C$. gigas living in high-turbidity environments (Dutertre et al., 2007; Beninger et al., 2008) and should be 
considered in bivalve ecophysiological models. Even with these improvements, the SFG model clearly remains an empirical model and some of the formulations proposed in this study, such as the maximum somatic growth or post-spawning time-lag processes, already proposed in an earlier SFG mussel model (Brylinsky and Sephton, 1991; Scholten and Smaal, 1998), are probably species- and site-specific. The formulation of energy allocation, modified from that of Brylinsky and Sephton (1991), is clearly more elegant than the net production calculation, but respiration is still interpreted simply as losses (e.g. van der Meer 2009, Lika and Kooijman in press -this issue).

Despite their weaknesses, both the SFG and DEB models may prove useful as management instruments when used to assess orders of magnitude or to retrieve spatial structure at the scale of an ecosystem. Detailed information about feeding processes, such as clearance or biodeposition rates, has also been used to obtain an overview of the impact of suspension feeders on food resources, based on remote sensing data (IOCCG, 2009; Thomas et al. accepted, -this issue) or ecosystem modeling (Cugier et al., 2010). The growing interest in bivalve ecophysiological models is linked to their integration into farm models (e.g. Rosland et al., accepted, this issue) and ecosystem models (Grangeré et al. 2010) or decision-support tools for coastal planning and the integrated management of shellfish aquaculture (e.g. Ervik et al. in preparation; see a review in Ferreira et al. 2010). Ideally, these complex tools require efficient individual models with a limited number of parameters and sufficiently high levels of precision. Comparisons of the results of simulations generated by SFG and DEB approaches for different bivalve species in contrasting environmental conditions are important to provide the most reliable information possible at the individual scale before scaling aquaculture issues up to the population and ecosystem levels. For $C$. gigas, we showed that DEB and SFG oyster models require improvement if they are to become fully operational in coastal areas with high levels of turbidity.

\section{Acknowledgments}

This work received financial support from the European AquaDEB research group (http://www.ifremer.fr/aquadeb). We would like to thank Mathias Papin for taking care of the water quality probes.

\section{References}

Alunno-Bruscia, M. Bourlès, Y., Maurer, D., Robert, S., Mazurié, J., Gangnery, A., Goulletquer, P., Pouvreau, S. Accepted after minor revision. A single bioenergetics growth and reproduction model for the oyster Crassostrea gigas in six Atlantic ecosystems. J. Sea Res. -this issue.

Barillé, A.L., 1996. Contribution à l'étude des potentialités conchylicoles du Pertuis Breton. PhD thesis. University of Aix-Marseille II, Marseille, 312 pp.

Barillé, L., Héral, M., Barillé-Boyer, A.L., 1997a. Modélisation de l'écophysiologie de l'huître creuse Crassostrea gigas dans un environnement estuarien. Aquat. Living Resour. 10, 31-48.

Barillé, L., Prou, J., Héral, M., Razet, D., 1997b. Effects of high natural seston concentration on the feeding, selection and absorption of the oyster Crassostrea gigas. J. Exp. Mar. Biol. Ecol. 212, 149-172. 
Barillé, L., Haure, J., Pales-Espinosa, E., Morançais, M., 2003. Finding new diatoms for intensive rearing of the pacific oyster (Crassostrea gigas): energy budget as a selective tool. Aquaculture 217, 501-514.

Barillé-Boyer, A.L., Haure, J., Baud, J.P., 1997. L'ostréiculture en Baie de Bourgneuf. Relation entre la croissance des huîtres Crassostrea gigas et le milieu naturel: synthèse de 1986 à 1995. IFREMER report DRV/RA/RST97-16, 173 pp.

Bayne, B.L., 1976. Marine mussels, their ecology and physiology. Cambridge University Press, Cambridge, $506 \mathrm{pp}$.

Bayne, B. L., Hawkins, A. J. S., Navarro, E., 1987. Feeding and digestion by the mussel Mytilus edulis in mixtures of silt and algal cells at low concentration. J. Exp. Mar. Biol. Ecol. 111, 1-22.

Bayne, B.L., Hawkins, A.J.S., Navarro, E., Iglesias, J.I.R. 1989. Effects of seston concentration on feeding, digestion and growth in the mussel Mytilus edulis. Mar. Ecol. Prog. Ser. 55 (1), 47-54.

Beck, M.B., 1987. Water quality modeling: a review of the analysis of uncertainty. Water Resources Res. 23, 1393-1442.

Beninger, P.G., Valdizan, A., Decottignies, P., Cognie, B., 2008. Impact of seston characteristics on qualitative particle selection sites and efficiencies in the pseudolamellibranch bivalve Crassostrea gigas. J. Exp. Mar. Biol. Ecol. 360, 9-14.

Bernard, I., De Kermoysan, G., Pouvreau, S., Accepted after minro revision. Effect of phytoplankton and temperature on the reproduction of the Pacific oyster Crassostrea gigas: investigation through DEB theory. J. Sea Res. -this issue.

Bougrier, S., Geairon, P., Deslous-Paoli, J.M., Bacher, C., Jonquières, G., 1995. Allometric relationships and effects of temperature on clearance and oxygen consumption rates of Crassostrea gigas (Thunberg). Aquaculture 134, 143-154.

Bourlès, Y., Alunno-Bruscia, M., Pouvreau, S., Tollu, G., Leguay, D., Arnaud, C., Goulletquer, P., Kooijman, S.A.L.M., 2009. Modelling growth and reproduction of the Pacific oyster Crassostrea gigas: Advances in the oyster-DEB model through application to a coastal pond. J. Sea Res. 62, 62-71.

Brylinsky, M., Sephton, T. W., 1991. Development of a computer simulation model of a cultured blue mussel Mytilus edulis (L.) population. Can. Tech. Rcp. Fish. Aquat. Sci. 1805, $80 \mathrm{pp}$.

Cognie, B., Haure, J., Barillé, L., 2006. Spatial distribution in a temperate coastal ecosystem of the wild stock of the farmed oyster Crassostrea gigas (Thunberg). Aquaculture 259, 249-259.

Conover, W.J., 1999. Practical nonparametric statistics. 3rd edition, John Wiley \& Sons, Inc., New York.

Cugier, P., Struski, C., Blanchard, M., Mazurié, J., Pouvreau, S., Olivier, S., Trigui, J.R., Thiébaut, E., 2010. Assessing the role of benthic filter feeders on phytoplankton production in a shellfish farming site: Mont Saint Michel Bay, France. J. Mar. Syst. 82, 21-34.

Dutertre, M., Barillé, L., Haure, J., Cognie, B., 2007. Functional responses associated with pallial organ variations in the Pacific oyster Crassostrea gigas (Thunberg, 1793). J. Exp. Mar. Biol. Ecol. 352, 139-151.

Dutertre, M., Beninger, P.G., Barillé, L., Papin, M., Rosa, P., Barillé, A.L., Haure, J., 2009. Temperature and seston quantity and quality effects on field reproduction of farmed oysters, Crassostrea gigas, in Bourgneuf Bay, France. Aquat. Living Resour. 22, 319329.

Dutertre, M., Beninger, P.G., Barillé, L., Papin, M., Haure, J., 2010. Rising water temperatures, reproduction and recruitment of an invasive oyster, Crassostrea gigas, on the French Atlantic coast. Mar. Environ. Res. 69, 1-9.

Ervik, A., Døskeland, I., Hageberg, A., Strand, Ø., Hansen, P.K. In preparation. Virtual decision support tool (AkvaVis) for integrated planning and management in aquaculture. To be submitted to Aquaculture Environment Interactions. 
FAO, 2004. The State of World Fisheries and Aquaculture (SOFIA) 2004. Fisheries Department, Editorial Production and Design Group Publishing Management Service, Rome, p.153.

Ferreira, J.G., J. Aguilar-Manjarrez, C. Bacher, K. Black, S.L. Dong, J. Grant, E. Hofmann, J. Kapetsky, P.S. Leung, R. Pastres, Ø. Strand, C.B. Zhu, 2010. Expert Panel Presentation V.3. Progressing aquaculture through virtual technology and decisionmaking tools for novel management, pp. 91-93. Book of Abstracts, Global Conference on Aquaculture 2010, 22-25 September 2010. FAO/NACA/Thailand Department of Fisheries, Bangkok, Thailand.

Filgueira, R., Rosland, R., Grant, J. In press. A comparison of Scope for growth (SFG) and dynamic energy budget (DEB) models applied to the blue mussel (Mytilus edulis). J. Sea Res., -this issue.

Grangeré, K., Ménesguen, A., Lefebvre, S., Bacher, C., Pouvreau, S., 2009. Modelling the influence of environmental factors on the physiological status of the Pacific oyster Crassostrea gigas in an estuarine embayment; The Baie des Veys (France). J. Sea Res. 62, 147-158.

Grangeré, K., Lefebvre, S., Bacher, C., Cugier, P., Ménesguen, A., 2010. Modelling the spatial heterogeneity of ecological processes in an intertidal estuarine bay: dynamic interactions between bivalves and phytoplankton. Mar. Ecol. Prog. Ser. 415, 141-158.

Haure, J., Huvet, A., Palvadeau, H., Nourry, M., Penisson, C., Martin, JL.Y., Boudry, P., 2003. Feeding and respiratory time activities in the cupped oysters Crassostrea gigas, Crassostrea angulata and their hybrids. Aquaculture. 218, 539-551.

Haure, J., Papin, M., Dupuy, B., Nourry, M., Pénisson, C., Martin, J.L., Barillé, L., Dutertre, M., Rosa, P., Beninger, P., Barillé A.L., 2008. Étude de la croissance et de la reproduction de I'huître Crassostrea gigas en baie de Bourgneuf. SMIDAP report, 114 pp.

Hawkins, A. J. S., Bayne, B. L., Mantoura, R. F. C., Llewellyn, C. A., Navarro, E., 1986. Chlorophyll degradation and absorption throughout the digestive system of the blue mussel Mytilus edulis L. J. Exp. Mar. Biol. Ecol. 96, 213-223.

Hinch, S., Bailey, R.C., Green, R.H., 1986. Growth of Lampsilis radiata (Bivalvia:Unionidae) in sand and mud: a reciprocal transplant experiment. Can. J. Fish. Aquat. Sci. 43, 548552.

IOCCG. 2009. Remote sensing in fisheries and aquaculture. Forget, M.-H., Stuart, V., Platt, T., (eds.), Reports of the international Ocean-Colour Coordinating Group, No. 8, IOCCG, Dartmouth, Canada.

Kooijman, S.A.L.M., 2010. Dynamic Energy Budget Theory for Metabolic Organization,. Cambridge University Press, $3^{\text {rd }}$ ed.

Kooijman, S.A.L.M., 2006. Pseudo-faeces production in bivalves. J. Sea Res. 56, 103-106.

Lika, K., Kooijman, S.A.L.M., in press. The comparative topology of energy allocation in budget models. J. Sea Res., -this issue.

McKindsey, C.W., Thetmeyer, H., Landry, T., Silvert, W., 2006. Review of recent carrying capacity models for bivalve culture and recommendations for research and management. Aquaculture 261, 451-462.

Méléder, V., Barillé-Boyer, A.L., Baud, J.P., Barillé, L., Cognie, B., Rosa, P. 2001. Modélisation de l'affinage de l'huître Crassostrea gigas alimentée avec la diatomée Skeletonema costatum. Aquat. Living Resour. 14, 1-16.

Méléder, V., Launeau, P., Barillé, L., Rincé, Y., 2003. Cartographie des peuplements du microphytobenthos par télédetection spatiale visible-infrarouge dans un écosystème conchylicole. C. R. Biologies 326, 377-389.

Mølhenberg, F., Riisgård, H.U., 1979. Filtration rate using new indirect technique in thirteen species of suspension feeding bivalves. Mar Biol. 54, 143-147.

Pouvreau, S., Bourles, Y., Lefebvre, S., Gangnery, A., Alunno-Bruscia, M., 2006. Application of a dynamic energy budget model to the Pacific oyster, Crassostrea gigas, reared under various environmental conditions. J. Sea Res. 56, 156-167. 
Raillard, O., Ménesguen, A., 1994. An ecosystem box model for estimating the carrying capacity of a macrotidal shellfish system. Mar. Ecol. Prog. Ser. 115, 117- 130.

Ren, J.S., 2009. Effect of food quality on energy uptake. J. Sea Res. 62, 72-74.

Ren, J.S., Schiel, D.R., 2008. A dynamic energy budget model: parameterisation and application to the Pacific oyster Crassostrea gigas in New Zealand waters. J. Exp. Mar. Biol. Ecol. 361, 42-48.

Ropert, M., Goulletquer, P., 2000. Comparative physiological energetics of two suspension feeders: polychaete annelid Lanice conchilega (pallas, 1766) and the pacific oyster Crassostrea gigas (Thunberg, 1795). Aquaculture 181, 171-189.

Rosland, R., Bacher, C., Strand, Ø., Aure, J., Strohmeier, T. In press. Modelling growth variability in longline mussel farms as a function of stocking density and farm design. Journal of Sea Research, -this issue.

Scholten, H., Smaal, A.C., 1998. Responses of Mytilus edulis L. to varying food concentrations: testing EMMY, an ecophysiological model. J. Exp. Mar. Biol. Ecol. 219, 217-239.

Thomas, Y., Mazurié, J., Alunno-Bruscia, M. Bacher, C., Bouget, J.-F., Gohin, F., Pouvreau, S., Struski, C. Accepted. Modelling spatio-temporal variability of Mytilus edulis (L.) growth by coupling a dynamic energy budget model with satellite-derived environmental data. J. Sea Res., this issue.

Troost, K., 2010. Causes and effects of a highly successful marine invasion: Case-study of the introduced Pacific oyster Crassostrea gigas in continental NW European estuaries. J. Sea Res. 64, 145-165.

van der Meer, J., 2006. Metabolic theories in ecology. Trends Ecol. Evol. 21, 136-140.

van der Meer, J., 2009. An introduction to Dynmaic Energy Budget (DEB) models with special emphasis on parameter estimation. J. Sea Res. 56, 85-102.

van der Veer, H.W., Alunno-Bruscia, M., 2006. The DEBIB project: Dynamic Energy Budgets in Bivalves. J. Sea Res. 56, 81-84.

van der Veer, H.W., Cardoso, J.F.M.F., van der Meer, J., 2006. The estimation of DEB parameters for various Northeast Atlantic bivalve species. J. Sea Res. 56, 107-124.

van Haren, R.J.F., Kooijman, S.A.L.M., 1993. Application of the dynamic energy budget model to Mytilus edulis (L.). Neth. J. Sea. Res. 31, 119-133.

Ward, J.E., Levinton, J.S., Shumway, S.E., Cucci, T., 1997. Site of particle selection in a bivalve mollusc. Nature 390, 131-132.

Widdows, J., Fieth, P., Worrall, C.M., 1979. Relationships between seston, available food and feeding activity in the common mussel Mytilus edulis. Mar. Biol. 50, 195-207.

Wijsman, J., Smaal A.C. Submitted. Growth of cockles (Cerastoderma edule) in the Oosterschelde described by a dynamic energy budget model. J. Sea Res. -this issue. 
Table 1. Variables and parameter values of the SFG model used for Crassostrea gigas. Chla : chlorophyll a concentration, microalgae: microalgal concentration.

\begin{tabular}{|c|c|c|c|c|}
\hline & Abbreviation & Initial value & Units & References \\
\hline \multicolumn{5}{|l|}{ State variables } \\
\hline Reserves and gonad mass & RESGON & Value & G & \\
\hline Shell mass & SHELL & Value & G & \\
\hline Somatic mass & SOMA & Value & G & \\
\hline \multicolumn{5}{|l|}{ Forcing variables } \\
\hline Food proxy (Chl-a, microalgae) & $x$ & Field data & $\left.\mu g\right|^{-1}$, cells $\left.\right|^{-1}$ & \\
\hline Seawater temperature & TEMP & Field data & ${ }^{\circ} \mathrm{C}$ & \\
\hline \multicolumn{5}{|l|}{ Additional variables } \\
\hline Biomass lost with spawning & SP & 0 & G & \\
\hline Dry tissue mass & DTM & 0 & G & \\
\hline Functional response & $\mathrm{F}$ & $(0-1)$ & - & \\
\hline Maximal somatic growth & $\operatorname{Max}_{\text {SOMA }}$ & 0 & $G d^{-1}$ & \\
\hline Organic matter absorption & $\mathrm{ABS}_{\mathrm{ORG}}$ & 0 & $\mathrm{G} \mathrm{d}^{-1}$ & \\
\hline Organic matter ingestion & ING $\mathrm{ORG}$ & 0 & $\mathrm{mg} \mathrm{h}^{-1}$ & \\
\hline Respiration & RESP & 0 & $G d^{-1}$ & \\
\hline Temperature effect on ingestion & $\mathrm{ING}_{\mathrm{TEMP}}$ & 0 & $\mathrm{mg} \mathrm{h}^{-1} \mathrm{~g}^{-1}$ & \\
\hline \multicolumn{5}{|l|}{ Parameters } \\
\hline Absorption efficiency & $A e$ & 0.25 & - & This study \\
\hline Allometric exponent for ingestion & $B$ & 0.66 & - & Mølhenberg and Riisgård, 1979 \\
\hline Allometric exponent for respiration & $\mathrm{Br}$ & 0.8 & - & Bougrier et al., 1995 \\
\hline Center parameter for ingestion rate & $\operatorname{lng}_{1}$ & 0.06 & $\mathrm{mg} \mathrm{h}^{-1} \mathrm{~g}^{-1}{ }^{\circ} \mathrm{C}^{-2}$ & This study \\
\hline Maximal somatic growth parameter 1 & cms1 & 0.0293 & - & This study \\
\hline Organic absorption allocated to the shell & Shellcoef & 5 & $\%$ POM & Méléder et al., 2001 \\
\hline Conversion of $\mathrm{mg} \mathrm{O}_{2}$ into $\mathrm{mg} P O M$ & $\mathrm{mgO}_{2} \mathrm{pom}$ & 0.7 & $\mathrm{mg} \mathrm{POM} \mathrm{mg} \mathrm{O}{ }_{2}^{-1}$ & Barillé et al.,1997a \\
\hline Half-saturation coefficient & $X_{k}$ & Free fitted & - & \\
\hline Post-spawning time lag before shell growth & Tishell & 7 & $d$ & Méléder et al., 2001 \\
\hline Post-spawning time lag for gametogenesis & $T \lg$ & 15 & d & Méléder et al., 2001 \\
\hline Maximal organic ingestion & $I N G_{\max }$ & 22 & $\mathrm{mg} \mathrm{h}^{-1} \mathrm{~g}^{-1}$ & Barillé et al., 2003 \\
\hline Maximum RESGON threshold & Rgs2 & 0.6 & - & Dutertre et al., 2009 \\
\hline Temperature threshold triggering spawning & Ts & 18 & ${ }^{\circ} \mathrm{C}$ & Dutertre et al., 2009 \\
\hline Minimal temperature triggering gametogenesis & $\operatorname{Tg}$ & 8 & ${ }^{\circ} \mathrm{C}$ & Dutertre et al., 2009 \\
\hline Minimum RESGON threshold & Rgs1 & 0.2 & - & Haure et al., 2008 \\
\hline Minimum RESGON threshold triggering spawning & Rgsp & 0.35 & - & Pouvreau et al., 2006 \\
\hline Optimum temperature for ingestion rate & $\operatorname{lng}_{2}$ & 19 & ${ }^{\circ} \mathrm{C}$ & Bougrier et al.,1995 \\
\hline Respiration coefficient & resp1 & 0.2 & - & Haure et al., 2008 \\
\hline Respiration coefficient & resp2 & 0.1 & - & Haure et al., 2008 \\
\hline Spawning intensity & Cs & 60 & $\%$ & Dutertre et al., 2009 \\
\hline Reduction in shell growth during gametogenesis & Shellgam & 50 & $\%$ & Méléder et al., 2001 \\
\hline Threshold of somatic biomass & $\mathrm{Sm}$ & 1.5 & $g$ & This study \\
\hline Maximal somatic growth parameter 2 & $\mathrm{cms} 2$ & 0.044 & $\mathrm{~g} \mathrm{~d}^{-1}$ & This study \\
\hline
\end{tabular}


Table 2. DEB parameter values for Crassostra gigas from Bourlès et al. (2009).

\begin{tabular}{|c|c|c|c|c|}
\hline Parameters & Symbol & Units & Value & References \\
\hline \multicolumn{5}{|l|}{ Primary parameters: } \\
\hline Arrhenius temperature & $\mathrm{T}_{\mathrm{A}}$ & K & 5800 & Van der Veer et al. (2006) \\
\hline Half-saturation coefficient & $x_{k}$ & - & - & Free-fitting (see food proxy) \\
\hline Max. surface area-specific ingestion rate & $\left\{p_{x m}\right\}$ & $\mathrm{J} \mathrm{cm}^{-2} \mathrm{~d}^{-1}$ & 560 & Van der Veer et al. (2006) \\
\hline Assimilation efficiency & ae & - & 0.75 & Van der Veer et al. (2006) \\
\hline Volume-specific maintenance costs & {$\left[\mathrm{p}_{\mathrm{m}}\right]$} & $\mathrm{J} \mathrm{cm}^{-3} \mathrm{~d}^{-1}$ & 24 & Van der Veer et al. (2006) \\
\hline Maximum storage density & {$\left[E_{M}\right]$} & $\mathrm{J} \mathrm{cm}-3$ & 2295 & Van der Veer et al. (2006) \\
\hline Volume-specific costs for structure & {$\left[E_{G}\right]$} & $\mathrm{J} \mathrm{cm}^{-3}$ & 1900 & Van der Veer et al. (2006) \\
\hline Structural volume at sexual maturity & $\mathrm{Vp}$ & $\mathrm{cm}^{-3}$ & 0.4 & Bourlès et al. (2009) \\
\hline Fraction of $p_{c}$ spent on maintenance plus growth & $\kappa$ & - & 0.45 & Van der Veer et al. (2006) \\
\hline Fraction of reproduction energy fixed in eggs & $\kappa_{R}$ & - & 0.7 & Pouvreau et al. (2006) \\
\hline Shape coefficient & $\delta_{\mathrm{M}}$ & - & 0.175 & Van der Veer et al. (2006) \\
\hline \multicolumn{5}{|l|}{ Additional parameters: } \\
\hline Lower boundary of tolerance range & $T_{L}$ & K & 281 & Van der Veer et al. (2006) \\
\hline Upper boundary of tolerance range & $\mathrm{T}_{\mathrm{H}}$ & K & 305 & Van der Veer et al. (2006) \\
\hline Rate of decrease at lower boundary & $\mathrm{T}_{\mathrm{AL}}$ & K & 75000 & Van der Veer et al. (2006) \\
\hline Rate of decrease at upper boundary & $\mathrm{T}_{\mathrm{AH}}$ & K & 30000 & Van der Veer et al. (2006) \\
\hline Energy content of reserves (in ash-free dry mass) & $\mu_{\mathrm{E}}$ & $\mathrm{J} \mathrm{mg}^{-1}$ & 17.5 & Deslous-Paoli and Héral (1988) \\
\hline Gonado-somatic index triggering spawning & $\mathrm{Gl}$ & $\%$ & 40 & Bourlès et al. (2009) \\
\hline Temperature threshold triggering spawning & $T_{S}$ & ${ }^{\circ} \mathrm{C}$ & 22 & Bourlès et al. (2009) \\
\hline Lower boundary of tolerance range & $\mathrm{T}_{\mathrm{L}}$ & K & 276 & Bourlès et al. (2009) \\
\hline Upper boundary of tolerance range for ingestion & $\mathrm{T}_{\mathrm{H} \text { ing }}$ & K & 298 & Bourlès et al. (2009) \\
\hline Upper boundary of tolerance range for respiration & $\mathrm{T}_{\mathrm{H} \text { resp }}$ & K & 305 & Bourlès et al. (2009) \\
\hline
\end{tabular}


Table 3. Main differences and similarities between the Dynamic Energy Budget (DEB) and Scope For Growth (SFG) models used in this study to simulate the growth of Crassostrea gigas. See tables 1 and 2 for the meaning of symbols and acronyms.

\begin{tabular}{|c|c|c|}
\hline Main characteristics & DEB & SFG \\
\hline State variables & $\mathrm{E}, \mathrm{E}_{\mathrm{v}}, \mathrm{E}_{\mathrm{r}}$ & SHELL, SOMA, RESGON \\
\hline $\begin{array}{l}\text { Body size scaling } \\
\text { relationships }\end{array}$ & $\begin{array}{l}\text { Feeding proportional to surface } \\
\text { area }(\mathrm{S}) \text {, } \\
\text { maintenance proportional to body } \\
\text { volume }(\mathrm{V})\end{array}$ & $\begin{array}{l}\text { Empiric allometric exponents } \\
\text { for ingestion and } \\
\text { for respiration }\end{array}$ \\
\hline Pre-ingestive selection & No & No \\
\hline Ingestion & $\begin{array}{c}\text { Functional response } \\
X_{k} \text { adjusted } \\
\end{array}$ & $\begin{array}{c}\text { Functional response } \\
\mathrm{X}_{\mathrm{k}} \text { adjusted } \\
\end{array}$ \\
\hline Absorption efficiency & Constant & Constant \\
\hline $\begin{array}{c}\text { Temperature effect on } \\
\text { ingestion }\end{array}$ & Exponential relationship & Hyperbolic relationship \\
\hline $\begin{array}{c}\text { Temperature effect on } \\
\text { respiration }\end{array}$ & Exponential relationship & Exponential relationship \\
\hline Storage & $\begin{array}{l}\text { Explicit storage compartment } \\
\text { with its own dynamic }(E)\end{array}$ & $\begin{array}{l}\text { Absence of specific storage } \\
\text { formulation. Role played by the } \\
\text { reserves-gonads compartment } \\
\text { (RESGON) }\end{array}$ \\
\hline $\begin{array}{c}\text { Fate of assimilated } \\
\text { energy }\end{array}$ & $\begin{array}{l}\text { Stored, then allocated to soma } \\
\text { (fixed fraction ,K) and } \\
\text { reproduction (fixed fraction ,1-k) }\end{array}$ & $\begin{array}{l}\text { Allocated to soma (SHELL then } \\
\text { SOMA) then to reproduction } \\
\text { (RESGON) }\end{array}$ \\
\hline Maintenance priority & $\begin{array}{l}\text { Maintenance first paid by } \\
\text { reproduction buffer }\left(E_{r}\right) \text {, then by } \\
\text { somatic structures }(V)\end{array}$ & $\begin{array}{c}\text { Maintenance first paid by reserves- } \\
\text { gonads (RESGON) outside } \\
\text { gametogenesis period then by } \\
\text { somatic structures (SOMA) }\end{array}$ \\
\hline Reproduction & Process parallel to growth & $\begin{array}{c}\text { Gametogenesis triggered by a } \\
\text { temperature threshold }\end{array}$ \\
\hline Spawning & $\begin{array}{l}\text { Temperature and gonadosomatic } \\
\text { thresholds }\end{array}$ & $\begin{array}{l}\text { Temperature and gonadosomatic } \\
\text { thresholds }\end{array}$ \\
\hline Metabolic costs & $\begin{array}{l}\text { Distinct costs for structure and } \\
\text { maturity maintenance }\end{array}$ & $\begin{array}{l}\text { Respiration represents the total } \\
\text { metabolic rate of the organism }\end{array}$ \\
\hline
\end{tabular}


Table 4. Coefficients of determination ( $r 2$ ) of linear regressions for observed against simulated dry tissue mass of $\mathrm{C}$. gigas at the northern high turbidity (HT) and southern intermediate turbidity (IT) sites of Bourgneuf Bay, in 2005 and 2006. Simulations were conducted with DEB and SFG models for each food proxy: chlorophyll a (Chl-a) concentration and microalgal (Microalgae) concentration.

Chl-a

Microalgal concentration

\begin{tabular}{cccccc}
\hline \multicolumn{1}{c}{} & & \multicolumn{1}{c}{ DEB } & \multicolumn{1}{c}{ SFG } & DEB & SFG \\
& & & & & \\
2005 & IT & $0.31(p<0.05)$ & $0.26(p=0.05)$ & $0.70(p<0.001)$ & $0.28(p<0.05)$ \\
& HT & $0.32(p<0.05)$ & $0.65(p<0.001)$ & $0.94(p<0.001)$ & $0.06(p=0.38)$ \\
& & & & & \\
2006 & IT & $0.29(p<0.05)$ & $0.88(p<0.001)$ & $0.39(p<0.01)$ & $0.85(p<0.001)$ \\
& HT & $0.08(p=0.29)$ & $0.67(p<0.001)$ & $0.88(p<0.001)$ & $0.76(p<0.001)$ \\
\hline
\end{tabular}




\section{Figures}

Fig. 1. Location of the sampling sites in Bourgneuf Bay. Chlorophyll a concentrations were determined and oysters were sampled for biometric measurements at the northern highturbidity (La Coupelasse) and southern intermediate-turbidity (Graisselous) sites. Microalgal identification and concentration data were available for a low-turbidity site in the west of the bay (Bois de la Chaise).

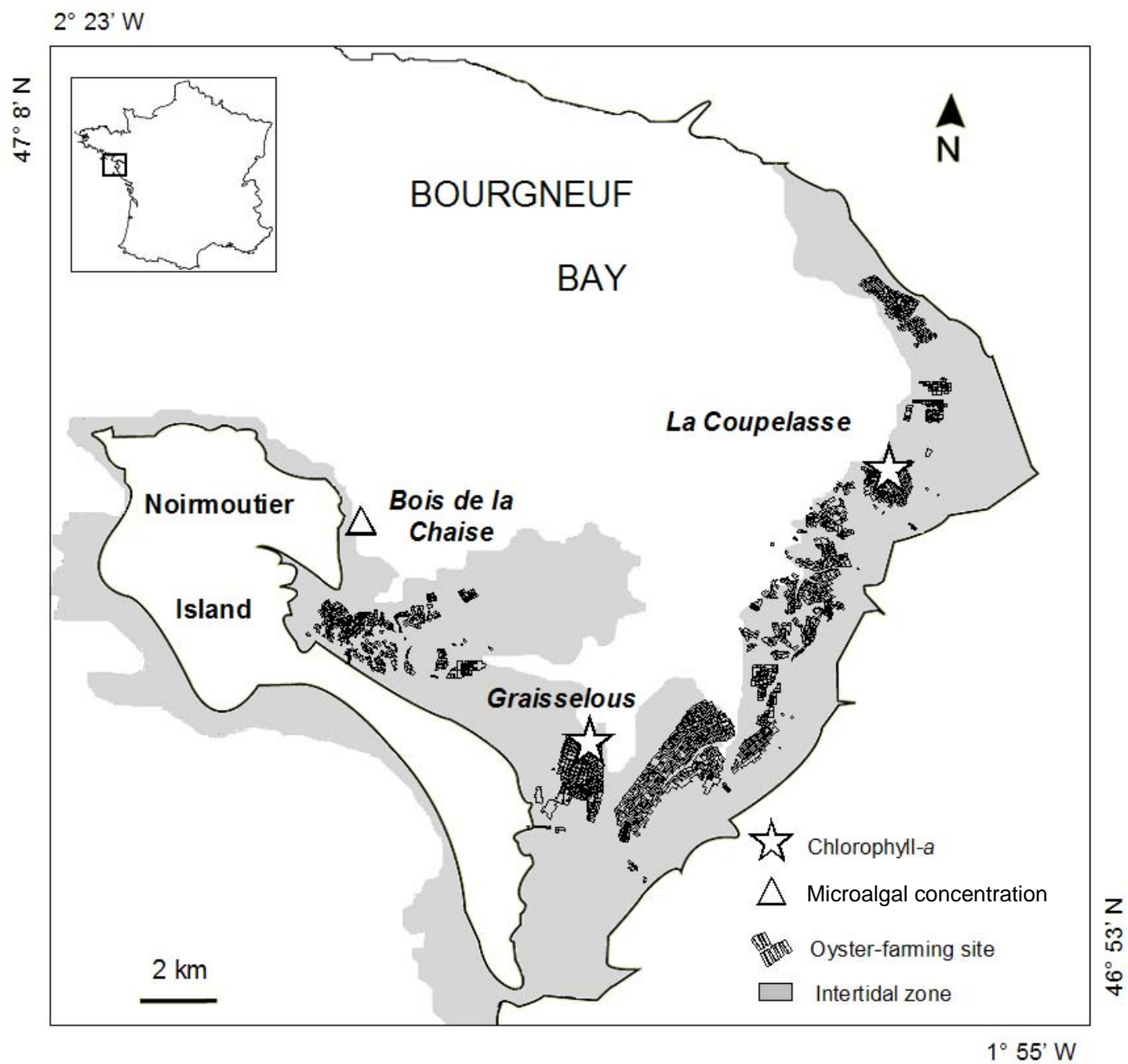


Fig. 2. Conceptual diagrams of the Scope for Growth and Dynamic Energy Budget models for the Pacific oyster, modified from Barillé et al. (1997a). Forcing variables are shown in the ellipsis while state variables are in the gray boxes..

\section{SFG model}

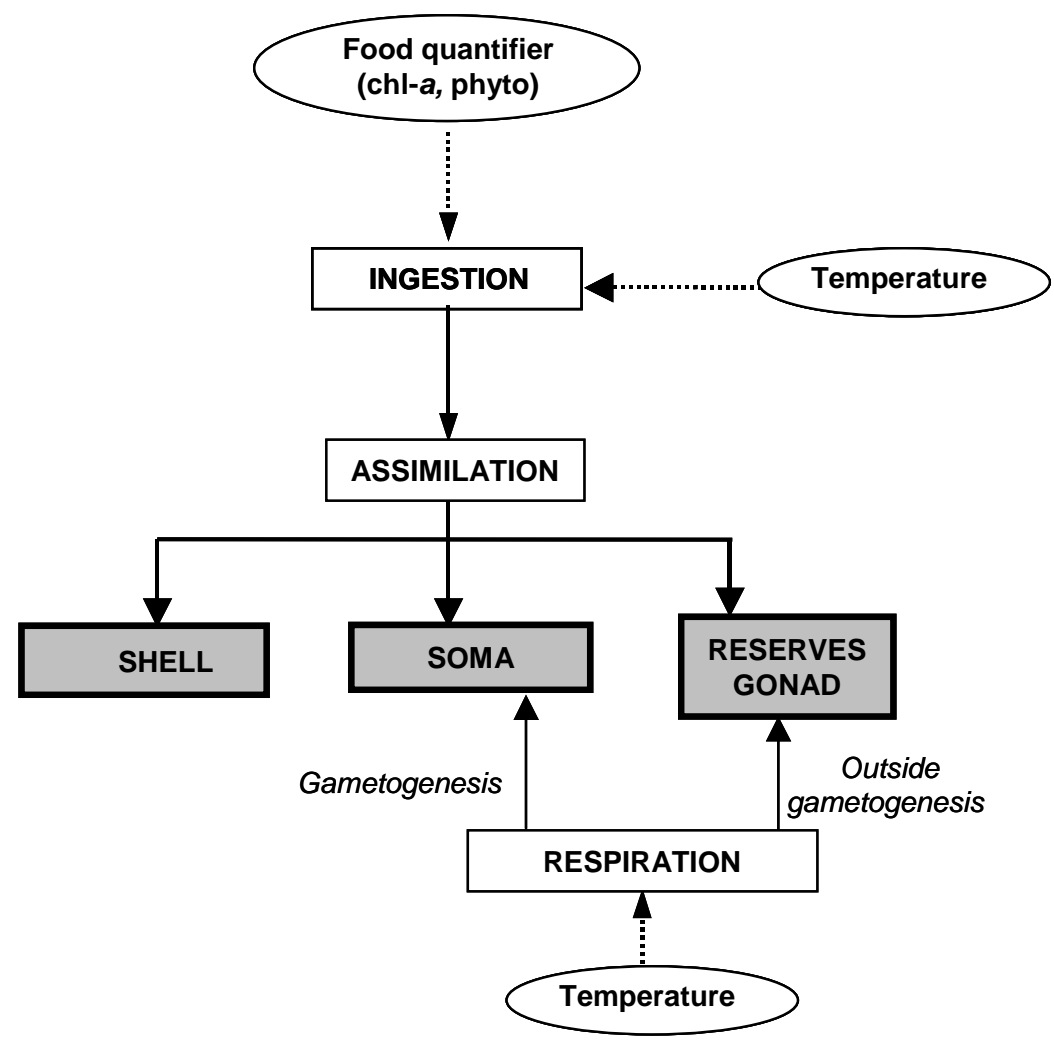

DEB model
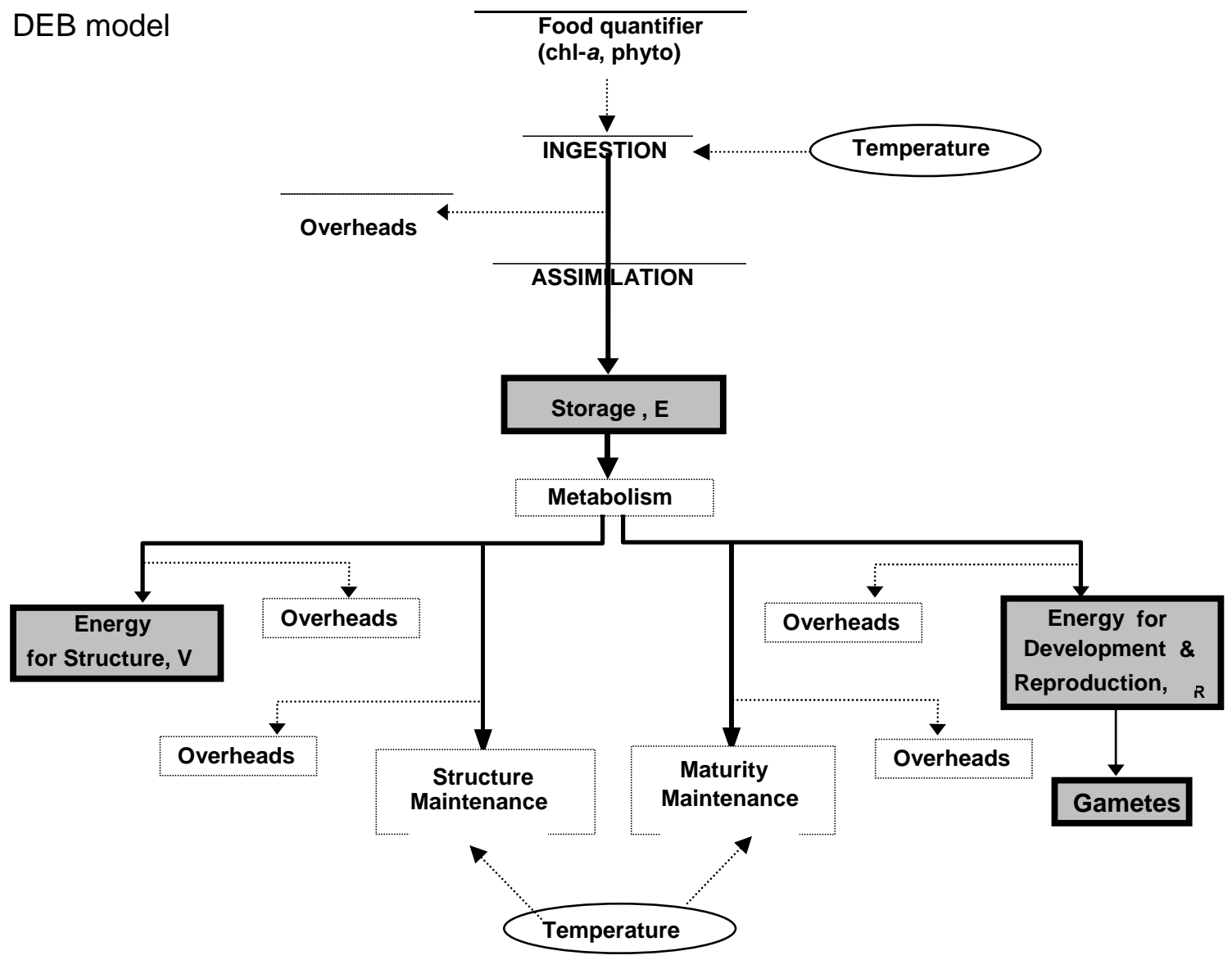
Fig. 3. Temporal variations of the forcing variables, monitored in Bourgneuf Bay from February 2005 to November 2006. Seawater temperature (a), suspended particulate matter (SPM, b) and chlorophyll a (chl-a, c) concentrations were recorded at the northern highturbidity (HT) and southern intermediate-turbidity (IT) sites of the bay, and microalgal concentration (d) was sampled at a site in the western part of the bay. Daily mean data are shown.
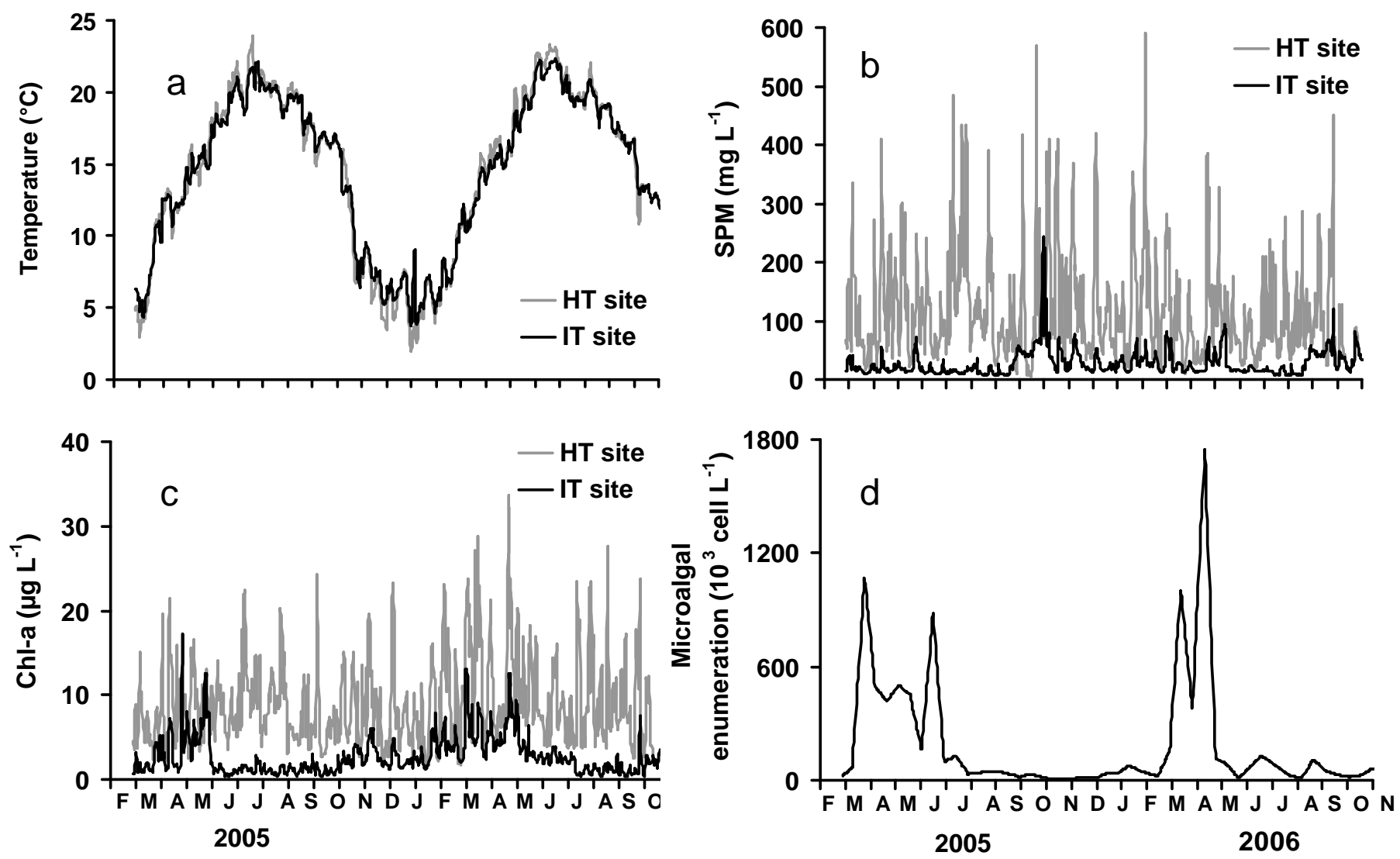
Fig. 4. Comparison between Pacific oyster dry tissue mass simulated by the SFG (gray line) and DEB models (black line) at the northern high-turbidity (HT) and southern intermediateturbidity (IT) sites of Bourgneuf Bay, with chlorophyll a as the food proxy. (a) IT site, in 2005. (b) IT site in 2006. (c) HT site in 2005. (d) HT site in 2006. Observed dry tissue mass is represented by symbols (mean $\pm 95 \% \mathrm{Cl}, \mathrm{n}=30$ ).
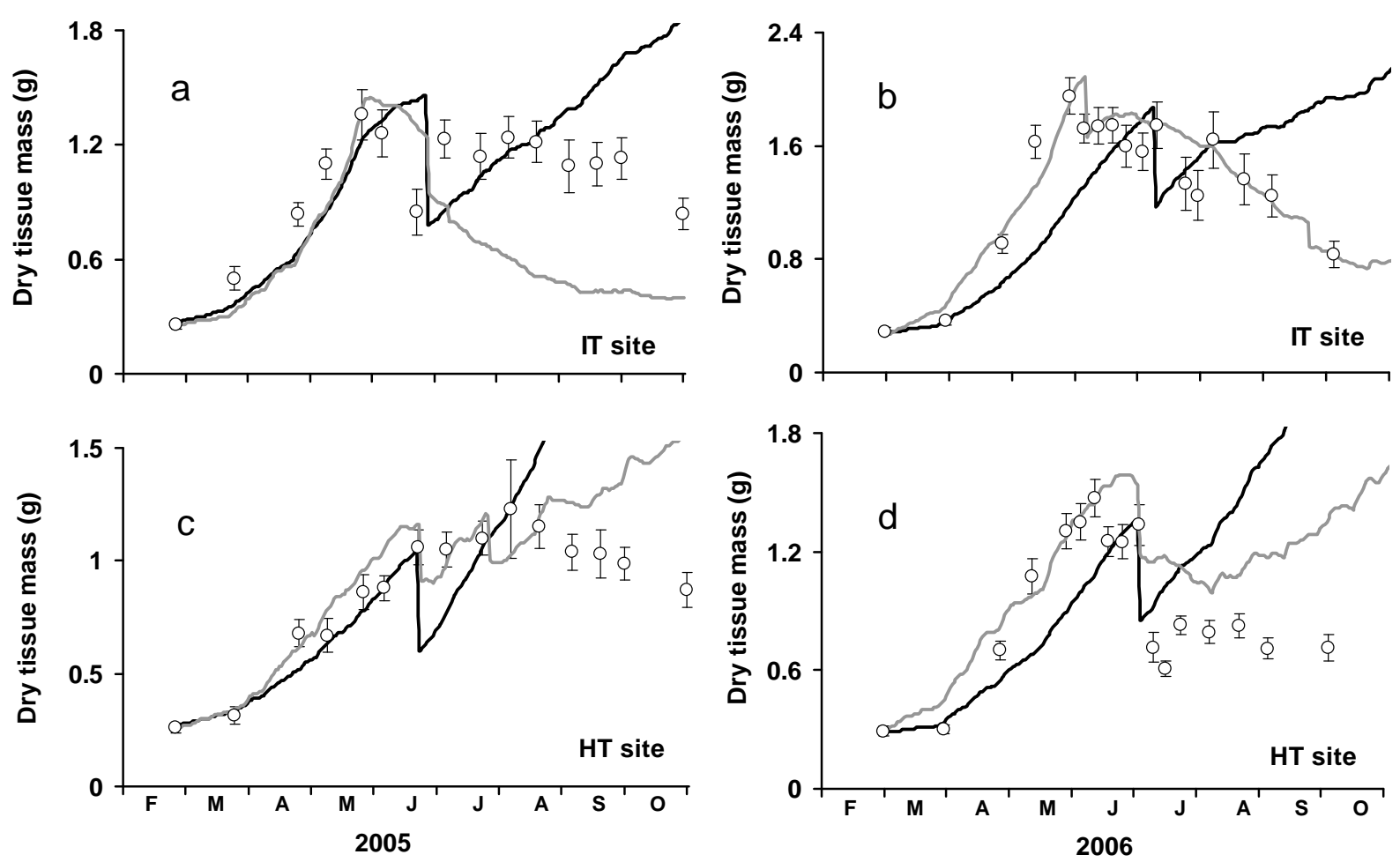
Fig. 5. Comparison between Pacific oyster dry tissue mass simulated by the SFG (gray line) and DEB models (black line) at northern high-turbidity (HT) and southern intermediateturbidity (IT) sites in Bourgneuf Bay, with microalgal cell concentration as the food proxy. (a) IT site, in 2005. (b) IT site in 2006. (c) HT site in 2005. (d) HT site in 2006. Observed dry tissue mass is represented by symbols (mean $\pm 95 \% \mathrm{Cl}, \mathrm{n}=30$ ).
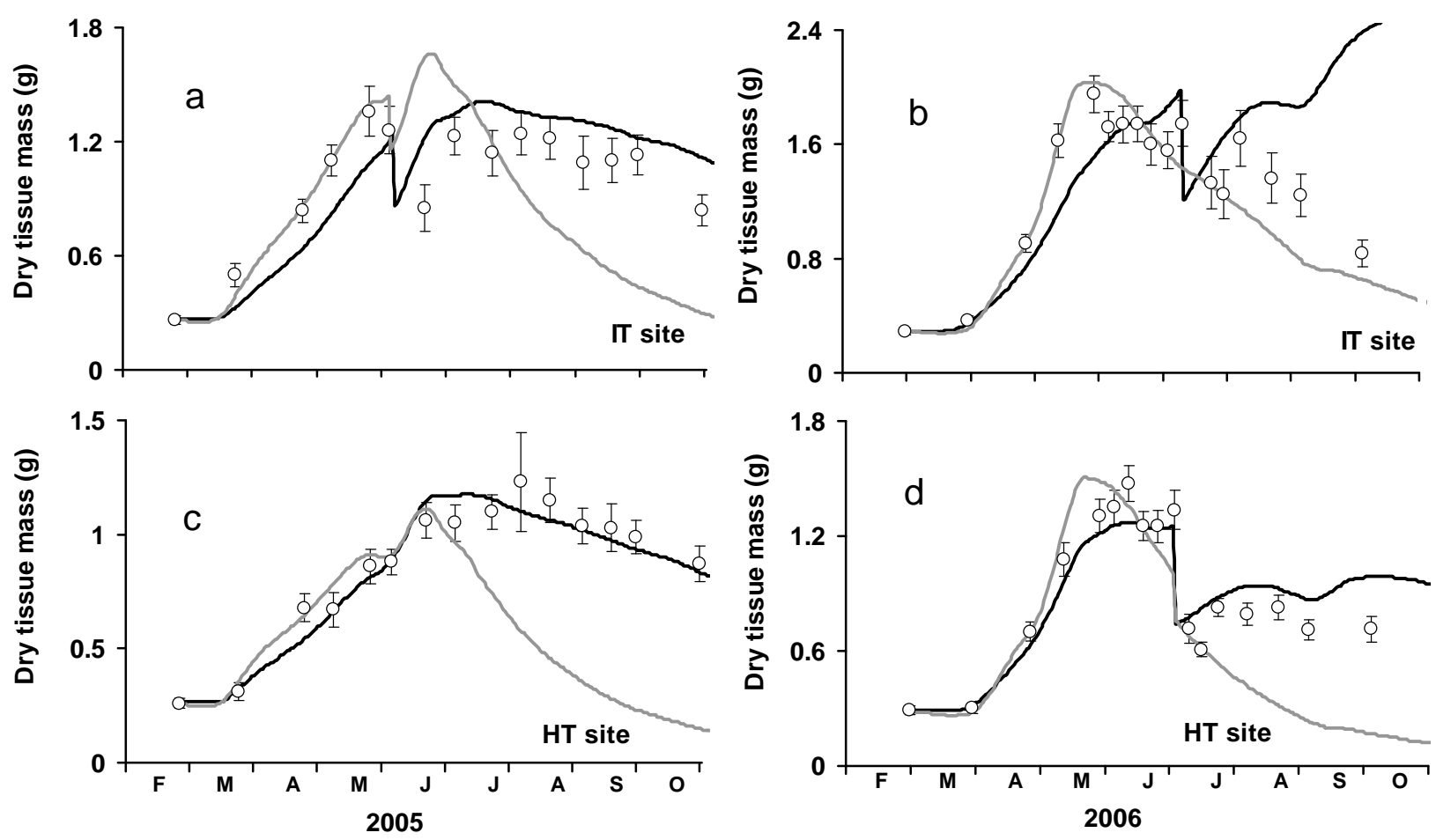